\title{
The Existing Problems of International Cooperative Talent Training Policy in Higher Education in Vietnam and the Reference of International Experience*
}

\author{
Anh Thu Vo \\ School of Humanties and Law \\ Northeastern University \\ Shenyang, China \\ Ho Chi Minh City University of Physical Education and \\ Sport \\ Ho Chi Minh, Vietnam
}

\author{
Wanbing Shi \\ School of Humanities and Law \\ Northeastern University \\ Shenyang, China
}

\begin{abstract}
The exploration of the existing problems and reference of international experienceof international cooperative talent training policy in higher education in Vietnam contributes to the improvement of the policy in Vietnam. Using statistical analysis method to reveal the existing problems of international cooperativetalent training policy in Higher education in Vietnam such as study aboard policy, the policy towards foreign teachers, training specialists and overseas Vietnamese, at the same time, analyzing and drawing lessons from the achievements of the policy of some typical countries in the word including the United States, Japan and China to improve the international cooperativetalent training policy in Higher education in Vietnam and to cultivate a group of high-end and internationalized human resources for the economic and social development of Vietnam.
\end{abstract}

Keywords-Vietnam; higher education; international cooperativetalent training policy; problems; international experience

\section{INTRODUCTION}

Every country in this world needs to be supported by capable human resources to maintain stability and development. Since the 21 st century, the prosperity of a country has depended on the students' diligence and assiduity and the development of the country has relied on scientific and objective education policy, international talent training policy, high-end talents training policy with the help of international cooperation, etc.

Vietnam in the process of economic globalization entrusted the educational responsibility to the Ministry of Education for organization and development, aiming at training a batch of able people who can meet international standards. Only with the power of international talents, can

*Fund Project: this paper is supported by Educational research project "Research on the funding system of postgraduate students in Northeastern University" of the postgraduate educational research program in Northeastern University, China.
Vietnam rise to the challenge of its integration into the world. In order to accomplish this important task, the Vietnamese government needs to have a correct understanding of international cooperative talent training related matters and introduce cooperative talent training policy in higher education with international standard. Facing the defects and problems of current high-end talent training policy cooperated by Vietnam and foreign countries, not only academic circles have become the focus of research, trying to reveal the problems of the policy, but also the Vietnamese government is needed to rack it's brain to handle with it.Therefore, the Vietnamese government must select the strategy of international cooperative training in higher education carefully, fixing its attention on a variety of angles, drawing lessons from the achievements of the developed countries in educationand conducting on-the-spot trials in Vietnam. It is feasible to draw on and learn from the advanced experience of other countries to improve and optimize the measures in Vietnam. No matter what method is adopted, it will be a good one if it can contribute to the country's economic and social development and to the prosperity of its educational development.

\section{THE EXISTING PROBLEMS OF ADVANCED} POSTGRADUATES TRAINING POLICY COOPERATED BY VIETNAM AND FOREIGN COUNTRIES

\section{A. The Existing Problems of Vietnam's Study Abroad Policy}

The government had attached great importance to studying aboard withthe main training objectsundergraduates and postgraduates 30 years ago when North and South Vietnam has not been liberated. At that time, the Vietnamese governmentsigned "Government cooperative training agreement" with Russia, China and other socialist countries to train scientific and technical personnel mainly and the process of itis divided into two stages. 
The first stage is nearly forty years from 1951-1990.The Vietnamese government dispatched 51999 students abroad, mainly postgraduate students, undergraduates, junior college students and interns, at the same time sent 97859 trainees to study abroad, mainly including skilled workers and professional teachers. At that time, the countries received to train Vietnamese students were Poland, Bulgaria, Germany, Hungary, the Soviet Union, Mongolia, Czech, etc. Until 1990, the market of studying abroad in Vietnam gradually became larger; countries receiving to train high-end Vietnamese postgraduates included Australia, Belgium, Holland, the United States, France, Thailand, etc.

The second stage is from 1990 to the present. The highly qualified postgraduate students trained by the cooperation of Vietnamese government and foreign countries were gradually increasing. In 1991, the Soviet Union was disintegrated and at the same time the cooperative training agreement between the Vietnamese government and the socialist countries was no longer in force, so the number of Vietnamese overseas students decreased. In the year of 1991, the Vietnamese government dispatched only 913 trainees to study abroad. Under a changing and complicated world background, the Vietnamese government still paid great attention to the development of cooperative training with foreign countries. The written decisions of the Fourth Session of the Seventh Central Committee Party, the Second Session of the Eighth Central Committee Party and the Sixth Session of the Ninth Central Committee Party of the Communist Party of Vietnam specially emphasized the development strategy of "science, technology, education, training" and at the same time focused on training postgraduate students cooperated with developed countries in the world, especially for senior postgraduate students. The main measures of higher educational human resources in the Second Session of the Eighth Central Committee Party of the Communist Party of Vietnam in 1996 emphasized the importance of cooperative training with other countriesand came up with some policies of strengthening international education and cooperative training. The Central Committee of the Communist Party in Vietnam proposed the idea of developing science-technology-education-training.At the same time, for the sake of social and economic development, the Vietnamese government has promoted friendship to all countries in the world extensively and deep, implemented a number of open policies in the society and economy and carried out a diversified, multiple and all-round foreign policy. In order to strive for a favorable international environment to safeguard the motherland and the cause of construction, the Central Committee formulated a general policy of "more friends, less enemies, creating a favorable international environment and serving for domestic economic development" and proposed that "we advocate and support the policy of peaceful coexistence between countries with different policies and social systems".

In July 29, 1995, Vietnam formally joined ASEAN and became its seventh member, which provided favorable conditions for Vietnam's economic development. In terms of the relations between Vietnam and the United States, Vietnam was opposed to uncooperative and hostile attitude in the past, taking breaking the U.S. embargo and improving the relationship between them. as one of the main directions, cooperating with the U.S. to search for missing persons in the Vietnam War, opening to the U.S. many secret materials related to the American prisoners of war in the Vietnam War and allowing American experts to visit some military units. Through the efforts of both sides, President Clinton announced "the normalization of the relations with Vietnam" in July 11, 1995 and the investment of American was gradually increasing. With the gradually improvement of the relations between the Vietnam and the United States, in terms of the relations between Vietnam and Japan, Vietnam and Europe, Vietnam and Australia, it has gradually become normal with continuous high-level exchange visits and strengthened economic and trade cooperation.High-level visits to the former Soviet Union and Eastern Europe also increased and the relations used to be interrupted returned to normal. All of these provided conditions for the development of the relations between Vietnam and the developed countries and a more favorable international environment for reform and opening up. As of January 11, 2007, Vietnam formally joined the WTO. It has spent all its political isolation and economic blockade period and restored normal relations with the international community, providing an unprecedented and favorable external environment for the reform, opening up and economic development. This is the international education cooperative training relationship of sustainable development, the unbreakable cooperative relations in higher education with the Vietnamese government and the other countries and the condition of international cooperative high-end postgraduates training.

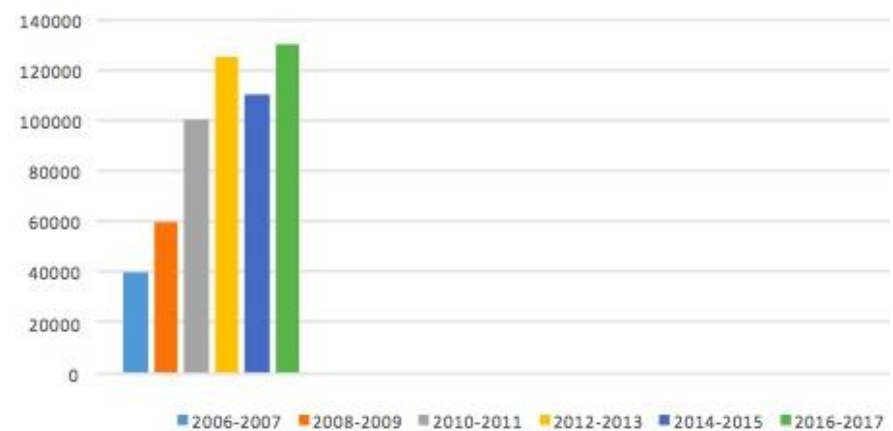

Fig. 1. An illustration of the increase of students studying abroad in Vietnam.

a. (Data source: the annual educational statistics of the Ministry of Education in Vietnam, in thewebsite of Ministry of Education in Vietnam: http://pbc.moet.gov.vn/, page=9.6)

At present, Vietnamese students have many channels to study abroad either at their own expense or with a wide range of scholarships. Ministry of Education in Vietnam vigorously mobilized students to study abroad who can apply for foreign government scholarships for education in Vietnam or the overseas postgraduate students studying abroad training project funded by national government (322 projects for short) The development of the 322 project produced a lot of regulations have to be complied. The key issue now is that the information on the Vietnamese government scholarship for studying abroad is not completely public without close link between education and training departments, good treatment, and sufficient research conditions and so on. 


\section{B. TheExisting Problems of the Policy towards Foreign Teachers and Training Specialistsin Vietnam}

Most of the scientific experts and lecturers coming to Vietnam for scientific research and teaching communication are volunteers and $90 \%$ of them are voluntary language teachers[1].This statistics illustrates a problem that the social and economic development of newly opened Vietnam needs not only the power of foreign languages, but also high-tech technical staff and scientific management personnel in other fields.In addition to the needs of foreign languages, Vietnam education and training organization urgently needs technical training experts, especially high-tech experts. Globalization and internationalization are the inevitable trend of human social development and the large market of manpower for equal competition without borders. Only human beings with real ability can survive, otherwise will be eliminated by historical development.

Vietnamese education is closed within the circle drawn by itself.Educational training policies are frequently revised butthe key is that outdated training methods and backward teaching content are not changed. The current reform is indeed a change in form but not in content. There is no appeal of treatment policies for foreign lecturers and the lecturers in Vietnam have not fully granted the right of scientific research independently.

\section{TheExisting Problems of the Policy towards Overseas Vietnamese in Vietnam}

At present, about four million Vietnamese live and work overseas, among which 300 thousand are undergraduate or postgraduate students. The value created by overseas Vietnamese is closed to $\$ 30$ billion annually. Among these overseas Vietnamese intellectuals, many are world famous celebrities or world class scientific experts who mainly live and work in the United States, Australia, Canada, the United Kingdom, Holland, Japan and other countries. For example, they are competent for teaching at Harvard University, Stanford University, Yale University, University of Tokyo, University of Sydney and other world-renowned universities, even shoulder heavy responsibilities and play a leading role in the world famous big corporation such as Apple Inc. (Apple), Microsoft Corp. (Microsoft), Monsanto, Mitsubishi and other companies.

A large amount of high-level overseas Vietnamese with high-tech knowledge training in foreign advanced environment mainly work in science and technology. The overseas Vietnamese intellectual is a precious power for the foundation of the country, the internal force in the sustainable development of society, economy, education, science, etc. in Vietnam, and it is also the support of integrating into the developing trends of countries all over the world.

According to the statistic data annually in Vietnam, over 200 groups of high-level overseas Vietnamese experts return to their mother country each year to participate in scientific activities of various fields, coming from some developed countries such as the United States accounting for $30.31 \%$, France accounting for $1.90 \%$, Australia accounting for $12.23 \%$, and Canada accounting for $7.97 \%$ [4] .
At present, the Vietnamese government has not a logical and reasonable treatment policies can make the high-level and famous overseas scientists be for the country. Most overseas Vietnamese return to take a short-term trip, visit relatives and friends, attend the meeting or symposium, etc. It is a difficult problem for Vietnam not having a well established treatment mechanism to keep the talents back to contribute to the motherland.

All in all, there are many difficulties in the cooperative training between Vietnam and other countries by now, especially the problem of the establishment, improvement and expansion of cooperative training policies, resulting in a large loss of Vietnamese studentstraining abroad and a serious phenomenon of brain drain and talent loss. There are not many foreign talents, scientific experts and high-level talents coming to Vietnam, and the comers and goers are all in a hurry. In recent years, the Vietnamese government has made no attempt to use the human resources as far as overseas Vietnamese volunteers are concerned. Although Vietnam has been acknowledged in the world as a country with rich potential, the Vietnamese government is unable to distinguish between good and evil about the policies it drafted. Frequent modification instead of stable policy leads to "armchair strategy" without practical effect, failing to attract high-level foreign talents and overseas Vietnamese geniuses.

\section{REFERENCE OF INTERNATIONAL EXPERIENCE OF INTERNATIONAL COOPERATIVE TALENT TRAINING POLICY IN HIGHER EDUCATION}

\section{A. The United States}

The United States is adeveloped country in society, economy, science and education with an advanced education system especially the higher education system. Students here have to graduate from a university (Undergraduate University) after four-year-schooling time firstly, then they will have the opportunity to study for the Bachelor of Science. After 2 years scientific research in Graduate University, they can get a postgraduate degree (M.Sc) or continue reading for doctoral degree (Ph.D.) which is the highest degree in the United States

But then, postgraduate students training is truly the core training program for students encouraged by American universities. According to the data in 1999, 7.7 out of 1000 Americans are senior postgraduate students (Master and Doctor), accounting for $16.6 \%$ in American college students. It is 1000 to 1.4 in Japan, accounting for $7.1 \%, 1000$ to 5.5 in the U.K., accounting for $20.9 \%$, and 1000 to 3.6 in France, accounting for $18.3 \%$.

The United States increasingly need science and technology experts to contribute to the sustainable development of the country. According to the statistic date of National Science Foundation, United States, an independent agency of the Federal, there were 26000 doctoral graduates in America from 1991-2000,among which American citizens accounted for $59 \%$ while citizens of other countries accounted for $38 \%$. According to the statistics, about 52\% doctoral students of non US citizens stayed in America for further study. 
The policy, social culture, economic development of the United States directly affects the development trend of the public universities. It can be concluded that the train of postgraduate students in higher education is the core of American education.

The United States has been a leading country attracted talents from other countries all the time with the well established talent treatment policy.Through a variety of rich and colorful international relations and international cooperative training relationship, itfulfills "special treatment policy towards postgraduate students of non US citizens", which is actually a mature talent attracting policy. Non US professors account for a high percentage in American universities and foreign doctoral students working in America in the high-tech field account for more than 50 percent. According to statistics, the proportion of senior postgraduate students stand for $40 \%$ of all the residents immigrated to the U.S., which means that the U.S. government attaches great importance to high-level talents training cooperated with foreign countries. In the 1990s, the United States had received over 100thousand high-level talents from foreign countries to work in America for a long time. In 2000, it had reached more than 500 thousand. The latest statistics show that nonAmerican teachers in universities of engineering in America account for $25 \%$.

\section{B. Japan}

The principles and characteristics of the current educational administrative system in Japan are determined by the Constitution, Education Basic Law, and the higher education of structure of Japan's educational system. Higher education in Japan has formed a multilevel and multi-type structure. According to the different sources of funds, it can be divided into three categories: state school, public school and private school. In terms of the academic level, higher education in Japan is second-level structure.

The primary structure means short-term universities and higher special schools, aiming at developing higher vocational education and cultivating practical living ability. The second structure means 4 year universities, including comprehensive universities, multiversities and colleges. The third structure is the graduate school including the research section and graduate school university set in the faculty, aiming at "instructing and researching academic theory and application, exploring the meaning as well as promoting the development of culture".

Japanese universities have a tradition of scientific research, mainly engaging in basic theoretical research. They take scientific research seriously, combining it with teaching as much as possible and pay attention to collaboration and joint research, especially industrial services. They try to establish a scientific research system of "the trinity of government, production and learning", concentrating on the power of the government, corporation and university, to carry out creative research and cultivate high-level pioneers so as to promote the transformation of the university from imitation scientific research to creative scientific research.
Since Edo (Tokchon time), Japanese education has started to spread European advanced knowledge, especially aiming at weak aspects of Japan. In order to attract high-level international talents, the Japanese government will also discuss the establishment of high-level talent exchange base in Kyoto for researchers and technical experts.

In 2005, 25.4480 of Japan's 286.5051 college students were postgraduate students. The Japanese government always encouraged students to study abroad; so many Japanese students were dispatch to abroad by the government. In the first few years of the 21 st century, Japan had entered the stable development stage in economy, society and all other aspects, at the same time, Japanese education had been gradually increased, which is said to be the first-class country in education in the developed countries of the world. It clearly shows that Japanese education policy is mature and study abroad policy is quite completed. According to the data published by Shanghai Jiao Tong University in China about the "100 strong" of 2016 world university academic rankings, four Japanese universities had their names on the list.

The Japanese government carried out training policy cooperated with foreign countries, which designates students to developed countries to study and employed world-class talents and high-level consultants to teach in Japan. It has been proved that after only a few years, Japan has accomplished industrialization and modernization with the fastest speed in the shortest time compared with all other countries in the world.

In the 1990s, Japan began to carry out Postdoctoral Fellowship Program, which was funded by Japan Society for Promotion of Science (JSPS). According to the annual statistics, JSPS provides 20 to 30 scholarships for foreign students each year, and JSPS even stipulates that the scholarship is specially designed for scientific research and research institutes in Japan. The application process of Japanese JSPS articles is very strict because of the provision of the Japanese government, in order to find foreign talents who can contribute to the development of Japanese economy, society, science and education in the future. This is indeed the Japanese government's foreign talents attracting policy.

\section{China}

In 1981, China had 130 thousanduniversity teachers, 2400 of whom were professors and 20700 were associate professor. By 1984, Chinese has 902 universities with 475 thousand students, 547 of whom were university level and college level, 273 training schools, and 82 vocational schools.

Chinese education reform and postgraduate training have been highly valued by the Central State Council. In 1982, 696 institutions had postgraduate students training authorization points and 196 institutions had doctorate authorization points. The Chinese government advocates the establishment of firstclass, leading and international ranking universities, which has prepared for domestic modernization drive. China implements special treatment policies to attract overseas talents, especially overseas Chinese, ethnic Chinese, non Chinese postgraduate students, undergraduates and so on, at the same time, it encourages Chinese students to pursue master degrees at home. 
By 1991, 248 universities in China had doctorate authorization points, 586 universities had master's degree authorization points, and some professional doctoral programs in some colleges of the universities were even world-class level.

To avoid cultivating talents for other countries, in other words, to resolve brain drain crisis, the Chinese government carry out a series of talents treatment policies. The most effective policies are the Scientific Research Foundation for the Returned overseas Chinese Scholars, Trans-century Training Programme Foundation for the Talents, Chang Jiang Scholars Program, One Hundred Person of President of the Chinese Academy of Science, National Science Fund for Distinguished Young Scholars, and Talent Project. The most directly changing is that all ethnic Chinese either at home or abroad coming back to contribute the motherland can retrieve the individual income tax, which is exclusive for talents foreign countries.

According to the statistics of Torch Center, Ministry of Science and Technology, China had nearly 490 business incubators in 2003, of which were 45 national overseas scholars pioneer parks ratified by Ministry of Science and Technology to appeal scientific talents of overseas Chinese to devote themselves to the development of the country. It is most obvious that the Chinese government carried out The Recruitment Program of Global Experts (1,000 Talents Plan) in 2008, mainly reflected in four aspects, firstly, providing equal platform for the development of career, secondly, granting certain financial support, thirdly, providing some convenient measures for life, fourthly, allowing orderly flow.In 2011, China initiated "The Recruitment Program for Foreign Experts", an important part of 1,000 Talents Plan. Special talent introduction plan for Non Chinese foreign experts aims at strengthening the important task and considerable interests of scientific research. They can serve as an important position, have the right to determine responsibility of scientific research projects and funds in the scope of duty and receive a convenient living condition, payroll subsidies, research grants, insurance matters and so on provided by the government. The source of these international research talents has a huge impact on the cause of education reform, and has promoted modern usage and cooperation in training a generation of Chinese international talents.

\section{CONCLUSION}

In the first ten years of the 21 stcentury, science and technology developed rapidly in the process ofglobalization, which is the development of knowledge economic market. The training of human resources has a very important significance in every country, especially the training of advanced postgraduate students. The Vietnamese government, which is in the process of economic market development, attaches great importance to cooperate with foreign countries in high-level postgraduate studentstraining. However, it is different from paying attention to a matter and accomplishing it effectively. Talking is easy and acting is difficult. The Vietnamese government is in the face of a economic plight and surrounded by economic crisis, serious inflation and currency plunged, in order to survive and create a sustainable developed country, the government should establish and improve the high-end postgraduate training system, especially improve senior postgraduate training policy cooperated with foreign countries.At present, in the predicament of limited educational funding, the first task of the Vietnamese governmentis to cooperate with foreign countries to improve senior postgraduate training policy. On the basis of Vietnam's education policy and training system, especially the analysis of the existing problems of training postgraduate cooperated with foreign countries, this paper aims to evaluate the highend postgraduate training cooperated with foreign countries. At the same time, with the success experience of cooperative training in several countries, it provides several measures for the Vietnamese government about the high-end postgraduate training cooperated with foreign countries, contributing to the cause of education and high-end human resources training in Vietnam.

To sum up, the Vietnamese government should adopt the following measures for the proportion of high-end postgraduate of human resources training cooperated with foreign countries, for the avoidance of brain drain and attraction of foreign talents.

- Establish and improve talents attraction policy. Improve treatment policy for Vietnamese domestic capable people, overseas Vietnamese talents, foreign talent, etc.

- The government grantsuniversities the full right of recruiting students and implementing various means of attracting talents independently.

- In order to remain high-end talents, the Vietnamese government should create good working conditions and research environments, and at the same time provide certain measures to facilitate life.

- It is necessary to create a socialist country with a comprehensive relationship of "government-societymarket economy-domestic and foreign intellectuals"and with a educational system reformaround freedom, equality, justice and the rule of law.

- Establish and improve the internal force of domestic universitiesin Vietnam, and make the key universities the core base ofscientific and technological innovation, research and development.

- Establish special treatment policy. Making use of national scientific development priority policy, national education development fund, strategy appropriation policy of postgraduate training cooperated with foreign countries to train a group of high-end experts, senior postgraduate students and at the same time attract overseas Vietnamese talents and foreign able people to contribute to the Vietnamese government as well as the society and economy of Vietnam, a socialist country.

The Vietnamese government should notconstrain students after graduation at abroad to return home immediately, but support students who continue to make scientific research at abroad to accumulate working experience in the short term. At the same time, establish national fund for studying abroad and 
formulate relevant measures and legal systems about school, discipline and the development of business and even adopt some economic constraint measures such as dispatching under the contract and sending back with additional penalty in case it is broken.

\section{REFERENCES}

[1] The Report on "Foreign Scientific Cadres and Skilled Workers Training Program Innovation in the New Era and the Improvement of Work Efficiency" held by the Vietnam Ministry of Education in Hanoi in February 1990 .

[2] The Fourth Congress of the Seventh National Congress of the Communist Party of Vietnam (CPC) in 1999, the Second Session of the Eighth Conference, the Sixth Congress of the Ninth National Committee, published by Hanoi State Politics Press.

[3] Annual Report of 2015 by Vietnamese Ministry of Education http://pbc.moet.gov.vn/?page $=11.10 \&$ spage $2=1$

[4] Statistics Report of 2015 of Statistical Department by the Ministry of Education of Vietnam

[5] http://download.ei-ie.org/Docs/WebDepot/EaG2016_EN.pdf

[6] http://www.oecd.org/edu/education-at-a-glance-19991487.htm

[7] ttp://mt.sohu.com/20160817/n464679000.shtml

[8] Japan's new "Basic Education Law" (full text) [J]. Foreign Education Research, 2009 (3): 9 6, 95.

[9] http://www.edu.cn/jiao_shi_pin_dao/bjzhaopin/bjyincai/201506/t201506 25_1280326.shtml

[10] Shi Wanbing, Yan Dan, Zhang Yuxin, et. al On the actions of educational administration to advance the internationalization of higher education in China[J]. Journal of Liaoning Administration College, 2004,6(1):100-101.DOI:10.3969/j.issn.1008-4053.2004.01.048.

[11] Cheng Xi. Retrospection on the Chinese dispatchment policy for overseas Students in 30 years after reform and opening up[J]. Journal of Xuzhou Normal University (Philosophy and Social Sciences Edition) ,2009,35(4):1-8.DOI:10.3969/j.issn.1007-6425.2009.04.001.

[12] Hu Guangling. Discussion on Vietnam's economic reform under the background of Reform and opening up [D]. Changsha University of Science and Technology, 2012.DOI:10.7666/d.Y2090438.

[13] Introduction to the opportunities and challenges of college education after Vietnam's access to the World Trade Organization issued by Vietnam National Education Association (2006). Hanoi publishing house.

[14] The Ministry of Education of the People's Republic of China. The supervision information platform of Sino-foreign cooperation in running school [EB / OL]. (2010-10-04) [2011-03-07]. Http: http://www.crs.jsj.edu.cn /index.php.

[15] Ma Jianzhang, Zou Hongfei. International scientific research cooperation is a shortcut to cultivate the comprehensive ability of graduate students [J] .Heilongiiang Higher Education Research, 2003 (2): 95-96. 